\title{
Analysis on Financing Difficulty of Chinese SMEs and Countermeasures Concerned: From the Perspective of Supply Chain Finance
}

\author{
Luhao Liu $^{1, \mathrm{a}^{*}}$ \\ ${ }^{1}$ School of International Trade and Economics, Shandong University of Finance and Economics, \\ Jinan, 250014, China \\ allhlsw@163.com
}

Keywords: SMEs; Supply chain finance; Countermeasures

\begin{abstract}
Small and medium-sized enterprises (SMEs), an essential part in China's economic society, are faced with great financing difficulty in development. By analyzing financing source of SMEs in this paper, it is believed that the reason for their financing difficulty is ascribed to the weakness in profits accumulation and shortage of external financing channel. On that basis, this paper puts forward a new financing channel-supply chain finance, and then lists three supply chain finance modes-confirming storage financing, accounts receivable financing and FTW(finance-transportation and warehouse) financing based on characteristics of supply chain finance, so as to offer some guidance and reference for solving financing problem of Chinese SMEs.
\end{abstract}

\section{Development Difficulty of SMEs}

According to main indexes of industrial enterprises above designated size in China Statistical Yearbook 2016, there were 383,148 enterprises registered in China, and SMEs accounted for 97.49\%[1]. Data show that Chinese SMEs contribute over $50 \%$ of the revenues, more than $60 \%$ of GDP and at least over $70 \%$ of idle labors transferred from rural area. It can be seen that SMEs are an indispensable part of China's economic society. According to data of National Bureau of Statistics of the People's Republic of China last year, main business income and total profits of large enterprise were RMB 42.1567 trillion and RMB 2.3582 trillion respectively; those of medium enterprises were RMB 27.2361 trillion and RMB 1.7983 trillion respectively and those of small enterprises were RMB 41.5925 trillion and RMB 2.4622 trillion respectively. Moreover, ratio of total profits and main business income of large enterprises were 5.59\%, 6.60\% and 5.91\% lower than that of medium enterprises and small enterprises. From this perspective, SMEs have profitability to some degree and great development potential. However, from the view of data issued by China Association of Small and Medium Enterprises in recent years, SMEs' development index (SMEDI) is not promising in recent years. As shown by Fig. 1, SMEDI dropped from more than 100 before the first quarter of 2011 to 92.8 in first quarter of 2017 , significantly lower than level before 2011. Why? 


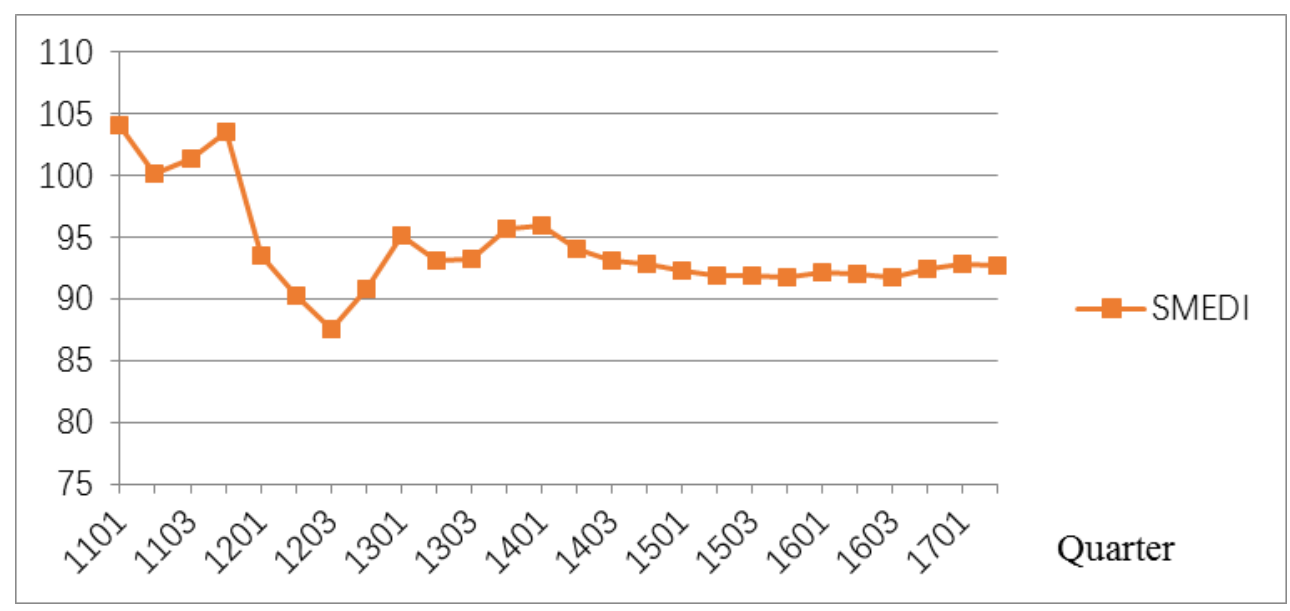

Figure 1 Development Index of Chinese SMEs

According to this paper, main reason for poor development of SMEs is involved with two aspects below:

Macro economy development slows down. From the perspective of macro level, China, after entering economic new normal, has slowed down its economic growth. QOQ growth rate of China's GDP shows a slow downtrend in recent years, according to data of National Bureau of Statistics of the People's Republic of China-China's GDP and GDP QOQ growth rate in 2012-2016. According to QOQ growth rates of national per capita disposable income and national per capita disposable income after deducting price factor in 2012-2016, actual growth rate of national per capita disposable income in 2016 was lower than GDP QOQ growth rate in the same year for the first time. This shows Chinese residents' pessimistic outlook for economy from another perspective, and consequently, consumers hold their wallet more tightly and market demand gets weak.

SMEs are faced with financing difficulty. Under such economic environment, SMEs were difficult to obtain financing support, regardless of good projects. In 2015, Chinese fixed assets investment of the whole society was RMB 56.2 trillion and reached RMB 60.6466 trillion in 2016, with a $7.9 \%$ growth, and actual growth rate after subtracting price factor was $8.6 \%$. But Chinese private fixed asset investment was RMB 36.5219 trillion in 2016, and growth rate was 3.2\%, which was far lower than $8.6 \%$ of that of the whole society[1].

As implied by data above, development of SMEs is influenced by macroeconomic situation and their financing channel during growth process is very limited. Data show that around $80 \%$ of Chinese SMEs are unable to get access to obtain bank loan. Unblocked financing channel retards development of SMEs obviously.

\section{Analysis on Financing Channel of SMEs}

Self-investment and internal accumulation. Financing channel of SMEs is very limited and the most common fund source is enterprise's self-owned funds and after-tax profits accumulated.

\section{Self-owned funds}

Investor's funds are mainly contributed by the owner and his or her relatives and friends, and a very small number of promising enterprises can obtain "Angel Investment". The amount of funds raised in this kind is closely related with individual reputation of owner and his or her relatives and friends and is so small that it cannot meet enterprise's demand. Even though enterprise obtains "Angle Investment" luckily, the company's later operation decision will be influenced, as investor will ask for the definite number of shares[2].

\section{Profits accumulation}

With the constant growth, SMEs can get profits surplus from operation. Besides dividends distributed to shareholders, enterprises will use the gradually accumulated tax-after net profits for their future development. Though foresaid ratio of total profits and main business incomes of SMEs is $6.6 \%$, higher than $5.59 \%$ of large enterprises, tax-after profits accumulated will not be large in 
quantity, in consideration of small scale of SMEs, small base number of main business income and long time consumption for profits accumulation. Therefore, for booming SMEs, only relying on profits accumulation is not enough to meet fund demand.

External financial support. External financial support that SMEs can obtain can be divided into loan, capital market financing and government's supporting fund.

\section{Loan}

Financing from financial institution

When SMEs seek external funds, bank will come to their mind first, but it is very hard to obtain bank loan for them. SMEs may lose opportunity for obtaining loan due to failure in providing guaranty and collateral conforming to bank requirement and even the failure in providing financial accounting statement meeting bank provisions resulted from incomplete financial system under small scale circumstance. Besides, even if they obtain loan, SMEs may miss commercial opportunity due to complicated bank loan procedure and long time waiting for loan; it is self-evident that this impacts SMEs more seriously in fierce market competition.

Private lending

Interest rate of private lending is far higher than bank loan rate in the same period. Though national laws specify: interest rate of private lending shall not exceed four times of similar bank loan, so as to control high interest rate of private lending, SMEs, in order to obtain fund, usually pay interest rate more than four times of bank loan rate in the same period. Another defect of private lending is risk and non-standardization. Private lending, though simplifying lending, brings about hidden danger, e.g. repaying failure of high interest rate may cause break of enterprise's capital chain. Private lending, often linked with "usury", "underground bank" and "gangdom", is a "thorny rose" for SMEs.

\section{Capital market financing}

SMEs can rely on capital market to raise fund for enterprise development, and the most common one is stock market financing. Although stock is low in issuing costs and needn't to be repaid, besides uncertainty for issuing stock to raise fund, new stocks issued by limited liability company need meet some certain conditions still, e.g. time limitation for equity financing, continuous profiting and distributing dividends to shareholder in recent three years, non-false record in recent financial accounting statement, and prospective earning being higher than bank deposit in the same period. Till the end of 2015, there had been 5,129 enterprises listed on National Equities Exchange and Quotations (commonly known as "New Third Board"), with total funds raised for RMB 1.121617 trillion. Till the end of 2016, there had been 10,163 companies listed on New Third Board; RMB 139.1 billion was raised totally, increasing by $14.4 \%$. But companies listed on New Third Board only accounted for $30 \%$ of SMEs in 2016; besides, not all listed enterprises could succeed in fund raising finally and actual number of enterprises obtaining funds is very small.

\section{Internet financing}

With internet development, some SMEs gradually take internet financing as one of financing channels. Internet financing, with low cost and high efficiency, can break geographical limitation [3]. However, it, as a newly sprouted thing, is much less complete than traditional financing system in development: System is incomplete and risk control ability is not outstanding; besides, fund amount raised from retail investor is limited. Therefore, this kind of funding mode cannot meet fund demand of SMEs. What is worse, internet financing becomes the subject of criticism after occurrence of the event that domestic internet financing enterprise "Ezubao" skips off with money, and its development is hindered.

\section{Government's support}

In order to encourage investment and consumption and promote economic development, loan interest rates of various financing institutions dominated by government are lowered to different degrees, which is good news for SMEs indeed. Besides, the state issues a series of subsidy programs to assist and support development of SMEs. Even so, difficulty for SMEs obtaining funds is great. There are two main reasons for it: First, SMEs are hard to obtain national special scientific research fund usually, as their product is labor-intensive mostly, product technicality is low and 
enterprise's R\&D ability is lacking. Second, Government's tax preference and subsidy are often under the premise of providing accurate accounting data[4], but SMEs have incomplete financing accounting system and are hard and even unable to provide accurate accounting data; therefore, they cannot enjoy preferential policies.

\section{Boosting Financing of SMEs through Supply Chain Finance}

Reason for SMEs' difficulty in financing can be summarized as follows: 1. Inadequate enterprise R\&D ability hinders profits accumulation and government subsidy application; 2. Incomplete enterprise financing accounting system handicaps bank loan and government subsidy application of SMEs greatly; 3. SMEs are incapable to provide enough collateral or guaranty to obtain bank loan. It can be seen from reasons above that SMEs are very difficult to obtain market financing just based on their own strength; only by other forces beyond enterprise, such as other cooperative enterprises in supply chain where they lie, can they obtain funds required for enterprise development[5]. Therefore, according to this paper, supply chain finance is a significant way to boost financing of SMEs.

Idea of supply chain finance. Supply chain finance, one special field for credit business of commercial bank and a kind of financing channel of enterprise especially for SMEs[6], means analyzing business of all enterprises in supply chain and applying self-liquidating trade finance mode to introduce core large enterprise, the third-party logistics enterprise and other risk control variables, so as to offer financing service including credit support and wealth management to different links of supply chain. The mechanism is shown in Fig. 2.

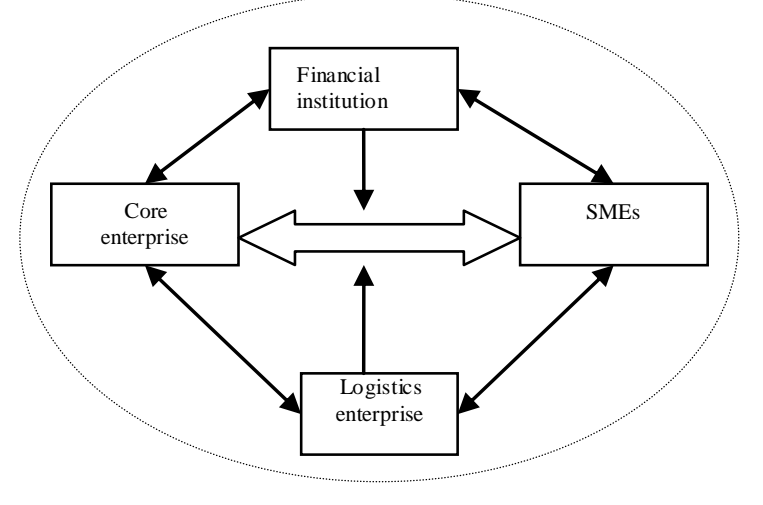

Figure 2 Mechanism of Supply Chain Finance

Different from traditional trade financing, supply chain finance mainly means implementing systematical financing arrangement oriented to all member enterprises in supply chain based on the cooperation agreement by and between core enterprises and bank; credit evaluation covers the whole supply chain rather than a certain enterprise[7]. It links up participants from perspective of capital flow, establishes new-type strategic cooperation relationship and completes credit allocation based on cooperative relationship among member enterprises; optimizes financing, lowers financing cost and improves capital use ratio by integrating enterprise's material, information and capital flows at junction point of supply chain. By virtue of characteristics above, supply chain finance becomes a financial instrument of SMEs, which are lacking of fixed assets and rich in current assets[8]. During production and operation based on core enterprise, SMEs have cash pressure from accounts receivable, advance payment and inventory occupation, and it is based on these three aspects that supply chain finance service is expanded, so as to improve credit capacity of SMEs.

Realization process of supply chain finance. Main realization type of supply chain finance includes confirming storage financing, accounts receivable financing and FTW financing.

Confirming storage financing refers to credit financing business implemented by pledging the established warehouse receipt of supplier in warehouse that bank designates (verifying loan limit) and controlling drawing rights of goods purchased under the premise of repurchase commitment of 
supplier (core enterprise). In light of the fact that material purchase or payment period of downstream enterprise in supply chain is short usually and upstream core enterprise asks for advance prepayment, downstream SMEs faced with capital turnover difficulty can choose confirming storage financing to obtain band credit support to realize prepayment.

Supplier, financing enterprise, financial institution and storage supervisor in supply chain will jointly participate in the process. To be specific, storage supervisor is mainly responsible for pledge evaluation and supervision; financing enterprise pays for goods by installments through confirming storage financing business, which relives financing pressure greatly, realizes financial lever principle and improves capital turnover ratio; core enterprise realizes batch sales. Precondition of confirming storage financing business is that upstream core enterprise in supply chain commits to repurchase material or product and undertake associative guarantee responsibility for SMEs and pledges established warehouse receipt of warehouse that financial institution designates, which lowers credit risk of financial institution.

Accounts receivable financing, which refers to mortgage finance behavior essentially, means getting short-term credit loan by pledging lots of packaged accounts receivable that enterprise has not received. This kind of financing mode, which is featured by convenience and strong operability, is generally oriented to upstream SMEs in supply chain. To be specific, SMEs can apply for short-term loan to financial institution by taking recourse rights of accounts receivables for core enterprise in supply chain as mortgage guarantee, but loan period should not exceed mortgage term of accounts receivable; bank and other financial institutions can review loan application of SMEs according to relevant data and experience accumulated and evaluate quality of accounts receivable based on enterprise's history operation data.

Differently, traditional credit business concerns assets scale and balance sheet information particularly; accounts receivable financing mode enables financial institution to pay more attention to trade contract signed by relevant enterprises in the whole supply chain and evaluate enterprise's ability to pay and potential risk factor according to main business status in supply chain and actual earnings performance of financing enterprise reflected in contract, so as to expand evaluation scope from single enterprise to the whole supply chain where the enterprise stays. Under joint function of such mutually constrained relevant guarantee mechanisms, SMEs in supply chain will establish steady commercial intercourse and excellent cooperative relationship gradually with core enterprise in their business, so as to make good credit record, increase their success probability for financing application and lower their financing cost; this also improves penalty cost dramatically in consideration that their financing will be influenced in case of contract breach and other risk accidents.

FTW financing means the integrated innovative service mode of providing logistics and warehousing service and financing service by a professional third-party logistics enterprise to financing enterprise. Under FTW financing mode, goods are not supervised in financing enterprise but in warehouse of the third-party logistics enterprise. To be specific, bank and other financial institutions will give the third-party logistics enterprise definite credit line according to its scale, performance, assets and liabilities, and the third-party logistics enterprise will divide credit line of bank and other financial institutions and then grant credit to financing enterprises in supervision warehouse. For this financing mode, credit quota is allocated according to credit condition of financing enterprise, goods that financing enterprise pledges in financing warehouse serve as collateral or counter guarantee and financing is based on credit guarantee, so as to simplify loan flow and lower transaction expense. FTW financing mode enjoys vast application prospect, as it can provide hi-tech prospective borrower to bank and other financial institutions, new channel for financing of SMEs as well as logistics value-added service for the third-party logistics enterprise.

\section{Conclusion}

In general, under the financing mode of "supply chain finance", SEMs obtaining bank's support in supply chain mean integrating into supply chain, so as to activate operation of the whole "chain". In addition, SMEs can win more commercial opportunities by means of bank's credit support. But it 
should also be noted that current supply chain finance, which is in preliminary stage of development, is faced with incomplete business and management modes and unreasonable financing mode. Therefore, in following research, it is imperative to explore rational and efficient applicable supply chain finance mode still, so that the mode can boost development of Chinese SMEs.

\section{Acknowledgements}

Capital project: Shandong Province Natural Science Fund project "Research on the Service Innovation of Agricultural Social Enterprises under the Constraints of Dual Objectives" (ZR2017MG010); Shandong Province High School Humanities and social science research projects "New Thinking and Realization of Agricultural Supply-side Reform in Shandong Province-Based on Social Enterprise Perspective(J17RB140)

\section{References}

[1] National Bureau of Statistics of China: Statistical yearbook of china 2016(China Statistics Press, China, 2017).

[2] Allen B, Udell N, Gregory F: The economics of small business finance: The roles of private equity and debt markets in the financial growth cycle. Journal of banking \& finance, 22(1998), No.6, p.613-673.

[3] Luc L, Does financial liberalization reduce financing constraints?. Financial Management, 32(2003), No. 1, p.5-34.

[4] Song Zhu, Minghua Gao: Research on the Influence of Government Support on the Development of SMEs(Economic Science Press, China, 2016).

[5] Tianli Zhong: SMEs Fiancing and Mutual Guarantee(Economic Science Press, China, 2016).

[6] Xuehao Feng,; Ilkyeong Moon,; Kwangyeol Ryu,. Supply chain coordination under budget constraints. Computers \& Industrial Engineering, 88(2015), No.10, p.487-500.

[7] Junhong Yan, Xiangtai Xu. Analysis on Financing model of SMEs Based on Supply Chain Fianace. Shanghai Finance, 16(2007), No.2, p.14-16.

[8] Karolin Kirschenmann, Credit rationing in small firm-bank relationships. Journal of Financial Intermediation,26(2016), No.4, p.68-99. 